\title{
The role of religious coping as a moderator of the relationship between psychological burden and quality of life among caregiver of women with breast cancer
}

\author{
Rully Afrita Harlianty ${ }^{1^{*}}$, Ira Paramastri ${ }^{2}$ \\ ${ }^{1 *}$ Departement of Psychology Faculty of Social and Business Universitas Aisyah Pringsewu \\ Jl. A. Yani 1A Tambahrejo Kecamatan Gadingrejo Kabupaten Pringsewu Lampung 35372 \\ 2 Faculty of Psychology, Universitas Gadjah Mada \\ Corresponding email: rully.afrita.h@mail.ugm.ac.id
}

\begin{abstract}
The aim of this study is to determine the relation between psychological burden and quality of life moderated by religious coping among caregiver of women with breast cancer. Total of subjects in this study were 70 family caregivers of women with breast cancer in Intensive Cancer Center "Tulip" Dr. Sardjito Hospital. Data were collected using three scale such as WHOQOL-BREF to measure quality of life which has been previously adapted in Bahasa Indonesia, and Psychological Burden Scale to measure psychological burden and Religious Coping Scale to measure religious coping, were both measurement from previous study which were modified to fit the subjects of study. Analysis of data using Moderated Regression Analysis. This study showed that psychological burden significantly predict quality of life $(B=-0,388 ; p$ less than 0,01 ) with effective contribution 15 percent, whereas religious coping was not proven to moderate the relation between psychological burden and quality of life ( $p$ more than 0,05). In conclusion, psychological burden could affect quality of life among caregiver of women with breast cancer. Religious coping did not moderate the relationship between psychological burden and quality of life among caregiver of women with breast cancer
\end{abstract}

Keywords: quality of life, psychological burden and religious coping

Abstrak. Penelitian ini bertujuan untuk mengetahui hubungan antara beban psikologis dengan kualitas hidup yang dimoderatori oleh koping religius pada caregiver wanita dengan kanker payudara. Subjek penelitian ini berjumlah 70 responden yang merupakan caregiver keluarga wanita dengan kanker payudara di Ruang Instalasi Kanker Terpadu "Tulip" RSUP Dr. Sardjito. Terdapat tiga alat ukur yang digunakan dalam penelitian diantaranya WHOQOL-BREF yang sudah diadaptasi sebelumnya ke dalam bahasa Indonesia untuk mengukur kualitas hidup, skala beban psikologis untuk mengukur beban psikologis dan skala koping religius untuk mengukur koping religius yang mana kedua skala merupakan skala yang sudah digunakan dalam penelitian sebelumnya dan dimodifikasi. Analisis data menggunakan Moderated Regression Analysis. Hasil penelitian ini menunjukkan bahwa beban psikologis secara signifikan memprediksi kualitas hidup $(B=-0,388, p$ kurang dari 0,01) dengan sumbangan efektif sebesar 15,0 persen, sedangkan koping religius tidak terbukti memoderatori hubungan antara beban psikologis dan kualitas hidup ( $p$ lebih dari 0,05). Kesimpulan dari penelitian ini adalah beban psikologis dapat mempengaruhi kualitas hidup pada caregiver wanita dengan kanker payudara. Koping religius tidak memoderatori hubungan antara beban psikologis dan kualitas hidup pada caregiver wanita dengan kanker payudara

Kata kunci: kualitas hidup, beban psikologis dan koping religius 


\section{Introduction}

Breast cancer is one of chronic disease that are commonly women as the patients. Based on data of basic health research in 2013, both cervix cancer and breast cancer are the highest prevalence cancer disease in Indonesia, with approximately $0,8 \%$ of cervix cancer and 0,5\% of breast cancer (Pusdatin Kemenkes RI, 2015). For the provincial level, D. I. Yogyakarta had the highest prevalence with approximately $2,4 \%$ in 2013. The patients who are diagnosed of cancer commonly will show some disruption symptoms both mentally and physically. The limitations in physical and mental after breast cancer diagnose are not only related with cancer disease, but also the treatments. Breast cancer treatments that are undertaken continuously in long-term commonly cause negative impact such as increasing anxiety and lesser overall quality of life in breast cancer patients (Charalambous, Kaite, Charalambous, Tistsi \& Kouta, 2017). In physically, chemotherapy and radiotherapy treatment could cause pain in breast cancer patients (Sarafino \& Smith, 2008). Consequently, breast cancer patients certainly are less capable to do daily activities because the disease and the treatments of breast cancer could affect both physical and psychological condition of breast cancer patients. So, breast cancer patients will need a help from caregivers to fulfill their needs.

Caregivers attempt to provide a care for their breast cancer relative or spouse physically, emotionally, socially and financially which result in neglecting their own needs (Schubart, Kinzie \& Farace., 2008), so that affect quality of life of caregivers (Kim \& Spillers, 2010). That is caused by caregiving tasks involving integration of complex skills that might make caregivers not being ready, or willing, or capable to do those tasks. Caregivers who are not ready to adjust of role change as caregivers for breast cancer patients risk to have low quality of life (Khanjari, 2012).

Poor quality of life especially mental health affected by caregiving burden for caring breast cancer patients ( $\mathrm{Zhu}, \mathrm{Fu}$, Wang, Lin, Fang \& Wang, 2014). Psychological burden of caregivers is one of psychological impacts that affect caregivers in providing a care for their sick family member. Higher level of burden has been related to higher level of physical and mental problems in caregivers who have higher burden found could predict depressive symptoms and poor self-health assessment (Fauth, in Leong, Altmaier \& Johnson., 2008). Zarit and colleagues defined caregiver burden is mutidimension reaction that caregiving has had adverse effects on caregiver resources including personal time, social roles, physical and emotional condition, and financial resources (Lu, Wang, Yang \& Feng.,2009; Adelman, Tmanova, Delgado, Dion \& Lachs., 2014). In conclusion, caregiver burden is conditions that affect physical, emotional, social and financial aspect caused by caregiving for sick one or having functional deterioration.

Religious coping could help caregivers as coping method in decreasing psychological burden. Heo (2009) said that religion might not really decrease work load or caregiving responsibilities, but it could increase caregiver's perception of their own resources such as feeling of mastery and personal belief. That perception, in turn, would affect how caregivers see their capability to fulfill demands and also decrease both stress and burden in themselves. Fider, Lee, Gleason, and Jones (2017) also revealed that caregivers who see God as love, does not control and sense the feeling of connected with church family (religious) have lower burden. By reducing psychological burden through religious coping, it could help caregivers to increase quality of life. Religious aspects such as a stronger feeling of connection with God, optimism, and hope could increase quality of life (Khanjari, Langius-Eklof, Oskouie \& Sundberg., 2014). Religious coping could help caregivers to reduce caregiving burden, however, if caregiving burden is not handled, it would affect quality of life. The previous finding reported by Zhu etc., (2014) showed that caregiver burden of spouse of women with breast cancer patients has negative impact on their quality of life, especially mental health. Caregivers burden has significant correlation with quality of life, so which results, the importance of reducing psychological burden than physical burden for caregivers. Hence, reducing caregivers burden through religious coping has important role for caregivers in order to be able in adapting to burden of giving a care, that might be related with low quality of life. 
According to theories and data of research above, researcher want to test the role of religious coping as a moderator of the relationship between psychological burden and quality of life among caregivers who give a care to breast cancer patients.

\section{Research Method}

\section{Variable Identification}

Variables that are used in this research are quality of life as criterion variable, psychological burden as predictor variable, and religious coping as moderator variable.

\section{Research Subject}

Subjects of this research are caregivers who give a care to breast cancer patients in Intensive Cancer Center "Tulip" Dr. Sardjito Hospital with some characteristics of subject involving family caregivers, such as husband or spouse, son or daughter, or other family relations and minimum adult age, 18 years old. The total of caregivers who became respondent of this research are 70 repondents.

\section{Research Instrument}

Data collection of this research using three scales such as WHOQOL-BREF is a self-reported 26aitem instrument that has been adapted in bahasa Indonesia to measure quality of life with satisfactory reliability of cronbach's alpha 0,905. Second, psychological burden scale is self-reported 29-aitems instrument thas was from previous study scale done by Ambarwati (2015). Test of reliability of psychological burden scale has been done by researcher with cronbach's alpha 0,929. And third, religious coping scale is self-reported 44-aitems instrument that was from previous study scale done by Sari (2016). Researcher did modification of the scale to fit the characteristic of subjects. Test of reliability of religious coping scale scale has been done by researcher with cronbach's alpha 0,909.

\section{Data Analysis Method}

Data analysis of this research using Moderated Regression Analysis (MRA), independent sampe ttest and one way anova. All data are analyzed by using SPSS 19 for windows.

\section{Results}

Based on correlation analysis, psychological burden had significantly negative correlatation with quality of life $(r=-0,388 ; p<0,01)$. There was also significant correlation between religious coping and quality of life $(r=0,338 ; \mathrm{p}<0,01)$. However, religious coping and psychological burden did not show correlation $(r=0,042 ; p>0,05)$. In conclusion, the correlation only show in psychological burden with quality of life and religious coping with quality of life.

For testing the hypothesis, moderated regression analysis was used. Moderated regression analysis was done by using hierarchical regression to analyze the functional of variable as moderator variable (Widhiarso, 2009). Hierarchical regression analysis is a stepwise analysis of inputting predictors in regression. Hence, hierarchical regression would obtain three models that are explained as follows; First model, psychological burden variable was regressed into quality of life variable. The result showed that psychological burden had significant role in predicting quality of life $(B=-0,388 ; p<0,01)$ with predictor contribution $15 \%\left(R^{2}=0,150\right)$. First hypothesis of this research was approved. Second model, both psychological burden variable and religious coping variable were regressed jointly into quality of life 
variable. There was enhancement of effective contribution $12,6 \%$ from $15,0 \%$ to $27,6 \%\left(R^{2}=0,276\right)$ with each variables' role were significant, psychological burden variable showed $B=-0,403(p \varangle 0,01)$ and religious coping variable showed $B=0,355(p<0,01)$. Based on that, in conclusion, both psychological burden and religious coping significantly predicted quality of life. Third model, including the interaction between psychological burden variable with religious coping variable to find out the moderating effects of variables. The result showed that only $0,6 \%$ of enhancement of effective contribution and it did not show moderating effect from interaction between psychological burden and religious coping ( $p>0,05)$. In conclusion, religious coping could not moderate the relationship between psychological burden and quality of life.

Based on the result, the relationship between psychological burden and quality of life moderated by religious coping could be visualized as follows:

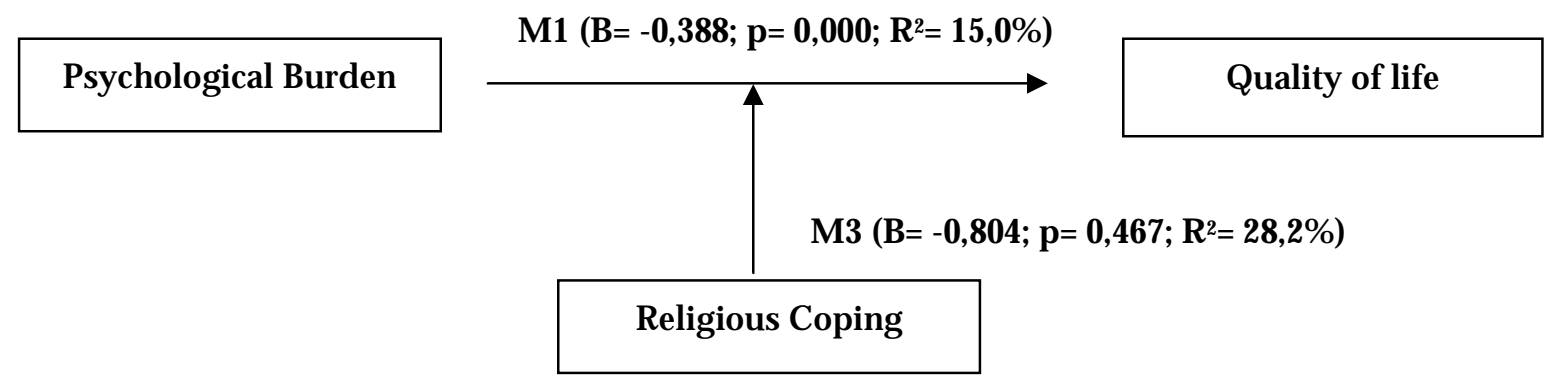

M2 (B

Researcher then did additional analysis test, it showed that sex, financial status, illness duration, relation to patient, age and educational level did not affect psychological burden ( $p>0,05)$. And so were with religious coping, there was no difference of religious coping among caregivers' sex, financial status, illness duration, relation to patient, age and educational level $(p>0,05)$. For quality of life, there was no difference of quality of life among caregivers' sex, illness duration and relation to patient $(p>0,05)$, whereas, financial status, age and educational level could affect quality of life among caregivers that will be explained as follows:

Financial status could significantly affect quality of life among caregivers $(p=0,016 ; p<0,05)$. Mean of quality of life among caregivers below 1.572.200 IDR was 87,60, whereas, mean of quality of life among caregivers above 1.572.200 IDR was 93,68. In conclusion, caregiver with higher financial status had better quality of life than caregiver with lower financial status.

For age, age could significantly affect quality of life among caregivers $(F=3,183 ; p=0,048 ; p<0,05)$. Based on LSD, there was significantly difference on quality of life between early-adult and late-adult ( $\mathrm{p}=$ $0,014 ; \mathrm{p}<0,05)$. Early-adult caregiver had higher quality of life that late-adult caregiver.

For educational level, educational level could significantly affect quality of life among caregivers $(\mathrm{F}=$ 3,183; $p=0,048 ; p<0,05)$. Based on LSD, there was significantly difference on quality of life between caregiver with educational level of primary and high school $(p=0,02 p<0,05)$. Caregiver with educational level of high school had higher quality of life than caregiver with educational level of primary. Beside that, there was also significantly difference on quality of life between caregiver with educational level of primary and university $(p=0,001 ; p<0,01)$. Caregiver with educational level of university had higher quality of life than caregiver with educational level of primary. However, there was no difference on quality of life among caregiver with educational level of high school and university $(\mathrm{p}>0,05)$.

\section{Discussion}

Based on data analysis, this research supported hyphotesis 1 that psychological burden significantly related to quality of life. Some previous studies supported this finding that psychological burden related 
to quality of life (McCullagh, Brigstocke, Donaldson \& Kalsa., 2005; Ogunlana, Dado, Oyewo, Odole, \& Ogunsan., 2014; Chuluunbaatar, Pu \& Chou, 2016; Srivastava, Tripathi, Tiwari, Singh \& Tripathi, 2016). Higher caregiving burden would affect quality of life of caregiver especially physical health. Ogunlana etc., (2013) said that psychological burden could affect quality of life on physical health domain that deteriorated. When caregivers offer caregiving to breast cancer patient, caregivers tend to neglect their own health to fulfill breast cancer patient's needs, so that it could decrease quality of life especially physical domain. Supported by Cordova, Canales, Krederdt, Gutierrez-Gomez, and Hernandez. (2015) stated about "work overload" phenomena among cancer caregivers that consist of: (1) neglecting of their own health, life project and social life; (2) poor family relationship; (3) feeling anxiety or frustration because of the lacking of trainings and skills in caring patient who is dependent fully or partially. Work overload was found to be related with quality of life especially mental and social dimension. Work overload becomes the cause of burden during providing a care among caregivers. Caregiving burden were consist of problems of some aspects such as hope, privacy, management, ashamed, anger, personal and social relations, fear, dependency, financial problems, inability, uncertainty, and avoidance (Srivastava etc., 2016). If conflict of those aspects could not be handled, it could lead to lower quality of life especially mental health domain such as stress, worried, and anxious in dealing with caregiving problem (Zhu etc., 2014), and social life (Cordova etc., 2016). Psychological burden could affect quality of life of caregivers in mental, physical, and social domain.

For hyphotesis 2, the data result showed that religious coping as a moderator of the relationship between psychological burden and quality of life among caregivers of women with breast cancer was not proven. This finding revealed that religious coping could not be predictor to strengthen and weaken the relationship between psychological burden and quality of life. Supported by previous study, Rathier, Davis, Papandonatos, Grover \& Tremont (2015) stated there was no evidence of some religious coping strategies or religious practices moderating the relationship between caregiving stress and depression in caregivers. Higher level of religious coping in working with God was related to higher level of depression. The use of religious coping reflects the perception that when stressor exceeds individual resources, individual asks God for a help which is the last way as psychological distress increases. Leblanc, Driscoll \& Pearlin (2004) also stated that religiosity could not moderate caregiving stress and stress among caregivers. That is because one of stressor, the feeling of an excessive caregiver's role was correlated with high level of self perception of religiosity. Caregivers feel burdened and bad, so that, protective function by identifying themselves as very religious ones involved. Hence, difficult situations make more stress among individuals who are more religious. Pearce \& Singer. (2006) said there were two possibilities that religious coping is related to higher caregiver burden. First, caregivers take many caregiving tasks cause those tasks are part of their religious obligation to help fellow individuals, so that, they feel burdened to fulfill those obligations. And second, the most burdened individuals turn to religion as coping stress and finding sacred meanings.

In conclusion, religious coping could not act as moderator variable cause of two possibilities, such as: first, caregivers who have high caregiving burden turn to religion as coping resource. When stressor becomes the cause of burden that exceeds individual resource, individual ask God's help as protective function to handle stressor. Second, feeling of excessive caregiver roles such as taking many caregiving tasks caused they are part of religious obligation to help the sick one so that caregivers feel burdened to fulfill the demands. If caregivers could not fulfill that religious obligation, they will feel guilty that lead to psychological problems such as increasing anxiety and depression. Stated by Lee (2007), more religious individuals easily feel more guilty which could lead to depression symptoms.

Based on correlation analysis, this research found that there was no correlation between religious coping and psychological burden. Caregivers who engange religiously do not mean to reduce psychological burden they experience while providing a care for their sick family member. Supported by previous study Miltiades \& Pruchno (2002) stated that religious coping did not relate to burden. Caregivers believe that God will help them to endure their daily burden, but they could not struggle to 
handle their life problems. Hence, religious coping helps caregivers to accept the burden, but not to reduce the burden.

This research also found that religious coping directly correlate to quality of life. This research result supported previous researches that religious coping correlate significantly to quality of life (Hosseini, 2013; Khanjari, Damghanifar, \& Haqqani, 2018). Coping through religion and spirituality approach supports stress-buffering that could buffer negative effects of stress, so that individuals could have better quality of life especially mental health (Colgrove, Kim \& Thompson., 2007). Religious coping could help individual to face negative circumtances in his or her life by positive changing that atributed to ask God's help, follow life purpose, increase relation with God through religious institution. And in the end, caregivers obtain a peace when they handle life difficulties that lead to quality of life especially mental health (Kim, Carver \& Cannady., 2015).

Based on additional analysis, this research found that there was difference quality of life of caregivers in financial status. Caregivers with higher financial status had higher quality of life than caregivers with lower financial status. Supported by previous studies showed that financial difficulty in caregivers could affect lower quality of life (Hashemian, Fallahi, Moghaddam Hosseini, Asadi \& Solemanian., 2013; Caqueo-Urizar, Alessandrini, Zendjidjian, Urzur, Boyer \& Williams., 2016; Chuluunbaatar, Pu \& Chou., 2016). Caregivers with poor or moderate economical status, and also they did not get supported by health insurance could impact lower quality of life.

This research also found that age could affect quality of life. Early-adult caregivers had higher quality of life than late-adult caregivers. Supported by Ogunlana etc., (2014) study that age had negative correlation with quality of life in caregivers. Older-age caregivers have lower quality of life. Because caregiving involves complex and multidimension activities, so that older-age caregivers tend to have more physical problems caused by providing a care to sick family member.

For educational level, it showed that caregivers with higher educational level had higher quality of life than caregivers with lower educational level. Supported by some previous studies that quality of life increased with higher level of education (Hashemian etc., 2013; Rha, Park, Song, Lee \& Lee., 2015). Level of education could influence caregiver's awareness and knowledge of care and complications related to care during the treatment of patient, so that they could adjust well. Caregivers who could not adjust well are at risk for obtaining psychological problems which caused by low level of education. Low level of education would experience more emotional distress that could affect life and poor physical health (Iconomou, Viha, Kalofonos, \& Kardamakis, 2001). In conclusion, low level of education affects poor quality of life in caregivers.

\section{Conclusion and Recommendation}

Psychological burden had a role in affecting quality of life among caregivers of women with breast cancer. High psychological burden was related to low quality of life, whereas low psychological burden was related to high quality of life. Religious coping was not proven as a moderator of relationship between psychological burden and quality of life among caregivers of women with breast cancer. However, if religious coping became independent variable, both religious coping and psychological burden could predict quality of life. For additional analysis, it found that quality of life was affected by demographic factors such as age, educational level and financial status. 


\section{References}

Adelman, R. D., Tmanova, L. L., Delgado, D., Dion, S., \& Lachs, M. S. (2014). Caregiver burden: a clinical review. Jama, 311(10), 1052-1060.

Ambarwati, W. (2015). Efektivitas program psikoedukasi kelompok dalam menurunkan beban psikologis pada family caregiver diabetes mellitus. Tesis. Yogyakarta: Magister Psikologi Fakultas Psikologi Universitas Gadjah Mada

Caqueo-Urízar, A., Alessandrini, M., Zendjidjian, X., Urzúa, A., Boyer, L., \& Williams, D. R. (2016). Religion involvement and quality of life in caregivers of patients with schizophrenia in Latin-America. Psychiatry research, 246, 769-775.

Charalambous, A., Kaite, C. P., Charalambous, M., Tistsi, T., \& Kouta, C. (2017). The effects on anxiety and quality of life of breast cancer patients following completion of the first cycle of chemotherapy. SAGE open medicine, 5, 2050312117717507.

Chuluunbaatar, E., Pu, C., \& Chou, Y. (2016). Caregiver Burden and Quality of Life of Informal Caregivers of Stroke Patients: A Prospective Study. Value in Health, 19(7), A658.

Colgrove, L. A., Kim, Y., \& Thompson, N. (2007). The effect of spirituality and gender on the quality of life of spousal caregivers of cancer survivors. Annals of Behavioral Medicine, 33(1), 90-98.

Córdova, M. I. P., Canales, R., Krederdt, S., Gutiérrez-Gómez, T., \& Hernandez, R. L. (2016). The relationship of the quality of life and burden of informal caregivers of patients with cancer in Lima, Peru. Journal of Nursing Education and Practice, 6(8), 36.

Fider, C. R., Lee, J. W., Gleason, P. C., \& Jones, P. (2017). Influence of Religion on Later Burden and Health of New Black and White Caregivers. Journal of Applied Gerontology, 0733464817703017.

Hashemian, M., Fallahi, A., Moghaddam Hosseini, V., Asadi, Z. S., \& Soleimanian, A. (2017). Evaluation of the Quality of Life of Female Family Caregivers of Patients with Breast Cancer in Iran (2013). Journal of Midwifery and Reproductive Health, 5(1), 821-827.

Heo, G. J. (2009). The role of religious coping in Alzheimer's disease caregiving (Doctoral dissertation, University of Pittsburgh).

Hosseini, E. (2013). A survey on the relationship between quality of life and religious coping in family caregivers of children with physical disabilities under covering of welfare organization in Ilam [Masters thesis]. Tehran University of Medical Science.

Iconomou, Anna Viha, Haralabos P. Kalofonos, Dimitris Kardamakis, G. (2001). Impact of cancer on primary caregivers of patients receiving radiation therapy. Acta Oncologica, 40(6), 766-771.

Khanjari, S. (2012). Quality of life in family caregivers to persons with breast cancer in iran- methodological and clinical aspects. Doctoral Thesis. Stockholm: Department of Neurobiology, Care Sciences and Society, Karolinska Institutet.

Khanjari, S., Langius-Eklof, A., Oskouie, F., \& Sundberg, K. (2014). Family caregivers of women with breast cancer in Iran report high psychological impact six months after diagnosis. European Journal of Oncology Nursing, 18, 630-635 New York: Springer Science + Business Media, LLC.

Kim, Y., Carver, C. S., \& Cannady, R. S. (2015). Caregiving motivation predicts long-term spirituality and quality of life of the caregivers. Annals of Behavioral Medicine, 49(4), 500-509.

Leblanc, A. J., Driscoll, A. K., \& Pearlin, L. I. (2004). Religiosity and the expansion of caregiver stress. Aging $\mathcal{E}$ Mental Health, 8(5), 410-421.

Lee, B. J. (2007). Moderating effects of religious/spiritual coping in the relation between perceived stress and psychological well-being. Pastoral Psychology, 55(6), 751-759.

Leong, F. T., Altmaier, E. M., \& Johnson, B. D. (2008). Encyclopedia of counseling (Vol. 2). Sage. 
Lu, L., Wang, L., Yang, X., \& Feng, Q. (2009). Zarit Caregiver Burden Interview: Development, reliability and validity of the Chinese version. Psychiatry and clinical neurosciences, 63(6), 730-734.

McCullagh, E., Brigstocke, G., Donaldson, N., \& Kalra, L. (2005). Determinants of caregiving burden and quality of life in caregivers of stroke patients. Stroke, 36(10), 2181-2186.

Miltiades, H. B., \& Pruchno, R. (2002). The effect of religious coping on caregiving appraisals of mothers of adults with developmental disabilities. The Gerontologist, 42(1), 82-91.

Ogunlana, M. O., Dada, O. O., Oyewo, O. S., Odole, A. C., \& Ogunsan, M. O. (2014). Quality of life and burden of informal caregivers of stroke survivors. Hong Kong Physiotherapy Journal, 32(1), 6-12.

Pearce, M. J., \& Singer, J. L. (2006). Religious coping among caregivers of terminally ill cancer patients. Journal of Health Psychology, 11(5), 743-759.

Pusdatin Kemenkes RI. (2015). Situasi penyakit kanker. Jakarta: Kementerian Kesehatan RI. Diunduh dari http:/www.depkes.go.id/resources/download/pusdatin/infodatin/infodatin-kanker.pdf.

Rathier, L. A., Davis, J. D., Papandonatos, G. D., Grover, C., \& Tremont, G. (2015). Religious coping in caregivers of family members with dementia. Journal of Applied Gerontology, 34(8), 977-1000.

Rha, S. Y., Park, Y., Song, S. K., Lee, C. E., \& Lee, J. (2015). Caregiving burden and the quality of life of family caregivers of cancer patients: the relationship and correlates. European Journal of Oncology Nursing, 30, 1-7.

Sarafino, E. P., \& Smith, T. W. (2010). Health psychology: Biopsychosocial interactions. United State of America: John Wiley and Sons, Inc.

Sari, T. W., \& Wisjnu, M. (2016). Peran koping religius dan dukungan sosial terhadap resiliensi pada janda usia madya pasca kematian pasangan hidup. Tesis. Yogyakarta: Magister Psikologi Fakultas Psikologi Universitas Gadjah Mada

Srivastava, G., Tripathi, R. K., Tiwari, S. C., Singh, B., \& Tripathi, S. M. (2016). Caregiver burden and quality of life of key caregivers of patients with dementia. Indian journal of psychological medicine, 38(2), 133.

Schubart, J. R., Kinzie, M. B., Farace, E. (2008). Caring for the brain tumor patient: family caregiver burden and unmet needs. Neuro-oncology, 10, 61-72.

Widhiarso, W., \& UGM, F. P. (2009). Prosedur Analisis Regresi dengan Variabel Moderator Tunggal melalui SPSS. Skripsi Falkutas Psikologi UGM.

Zhu, P., Fu, J. F., Wang, B., Lin, J., Wang, Y., Fang, N. N., \& Wang, D. D. (2013). Quality of life of male spouse caregivers for breast cancer patients in China. Asian Pacific journal of cancer prevention: APJCP, 15(10), 41814185 . 